\title{
Skin storage
}

\section{National blood transfusion centres could take on skin banking and distribution}

\begin{abstract}
"It needs no argument to convince trauma and plastic surgeons that one of the greatest needs at present is a readily available source of skin for covering large superficial areas of the body lost by trauma. Indeed, in certain eventualities the need may become desperate. It therefore behoves us to take stock and determine what shall be done."1
\end{abstract}

In Britain, 45 years after Pickerill wrote this, there is still no nationally available source of cryopreserved cadaveric skin. In the United States, however, skin banking is well established. The American Association of Tissue Banks (AATB), founded in 1976, lists 18 banks accredited to process allograft skin, most by cryopreservation. For the same per capita provision, one might expect four accredited skin banks in Britain. The newly formed British Association of Tissue Banks (BATB) drafted minimum standards for skin banking in June 1995. In Europe, skin banking is almost a cottage industry, with unregistered centres linked to burns units processing tissue for local use. There are about five such centres in Britain, most with inadequate organisation or funding to form part of a national network. Negotiations are in progress to incorporate at least one existing skin bank into the National Blood Service.

The optimal surgical management of large, life threatening burns is early excision and closure of the wound. Conventional closure of burns is accomplished by split thickness skin grafting, but autologous donor sites may be inadequate to cover large burns. In this instance allograft skin can be used in two ways: as temporary cover while available donor sites heal ready for reharvesting of split thickness skin grafts, or for a more permanent dermis to improve the take of cultured autologous keratinocyte grafts. The second method provides the highest clinical take rates for cultured keratinocyte autografts, as well as good quality, supple skin at long term follow up. ${ }^{2}$ Increased availability of allograft skin will facilitate early excision of burns and obviate the need for obtaining skin from living relatives or unrelated donors.

Using cultured keratinocytes in clinical practice has made it clear that stable closure of full thickness wounds needs dermis as well as epidermis. The ideal form of dermis contains living skin cells and is autologous. Dermis is a complex tissue and cannot be grown in vitro. No synthetic dermal replacement has been found to equal allograft dermis in closing wounds. Soluble proteins released by living dermal cells probably contribute to the dermo-epidermal interaction that improves grafting results. ${ }^{3}$ The closest compromise to autograft containing living cells is fresh or cryopreserved allograft skin. Cryopreservation is the only way to bank living allograft, and the process has been claimed to attenuate the antigenicity of the grafted skin. ${ }^{4}$

The use of allograft skin has been limited to large, full thickness burns; the risk of virus transmission from grafts containing living cells means that use of living allograft cannot currently be justified in smaller wounds. A single case of HIV transmission by donor skin has been reported. ${ }^{5}$ To limit the risks of virus transmission, allograft must be acquired from carefully selected and screened donors. The British Association of Tissue Banks recommends testing for HIV and hepatitis $\mathrm{C}$ virus based on polymerase chain reaction in cadaveric donors. However, these assays may yield false positive results from cadaveric blood samples ( $\mathrm{CH}$ Dellove et al. Third annual meeting of the European Association of Musculoskeletal Tissue, Leicester, 1994). As confidence in selection, screening, and testing of donors improves, living allograft may increasingly be used for non-life threatening wounds. In the meantime, non-living allograft, such as that provided by the Euroskin bank, which has been processed with high glycerol concentrations, seems the most appropriate preparation for use in small wounds. ${ }^{6}$
The ethical issues raised by skin banking relate to donor selection, consent, and testing, as well as allograft retrieval, processing, and distribution. The Council of Europe recommends that tissue banking should be carried out on a non-profit basis. ${ }^{7}$ In Britain there is a public perception that skin donation involves an unsavoury retrieval procedure, and there is no real appreciation that donor skin may be life saving. Skin is not included as an organ donation option on donor cards, and some transplant coordinators seem loathe to suggest skin donation. The method of skin graft harvest can be made acceptable by electric dermatome retrieval from the back and posterior thighs, which delivers about $30 \%$ of the body surface area. Organ retrieval is facilitated in countries with an "opt out" policy for donor consent. The Dutch Euroskin Bank has benefited from this system and is probably the only facility currently providing skin to third parties in mainland Europe.

In Britain, improved provision of cryopreserved skin is long overdue. Integrating and developing existing skin banks to provide a national facility will be more expensive than incorporating them into the infrastructure of the National Blood Service. Skin banking is a complex process, quite apart from the tissue preservation, and requires considerable resources. Proper costing should form the basis of cross charging in the same way that other essential services are provided in the NHS internal market. Regional blood centres in the United States have a proved track record in establishing tissue banking networks to meet community needs, ${ }^{8}$ and the same could apply in Britain. ${ }^{9}$ The National Blood Service has diversified and now banks bone, tendons, heart valves, placental cord blood, and peripheral blood stem cells. Many national blood transfusion centres have the appropriate infrastructure and qualified personnel to process donor skin. The minimal investment required to incorporate skin banking and distribution into its existing activities puts the National Blood Service at an advantage to take skin storage from under the mattress and into the bank.

$S$ R MYERS Research registrar

M R MACHESNEY Research registrar

Restoration of Appearance and Function Trust (RAFT), Mount Vernon Hospital,

Northwood,

Middlesex HA6 2RN

R M WARWICK

North London Tissue Bank,

Deansbrook Road,

London HA8 9BD

P D CUSSONS

Regional Burns Unit,

Mount Vernon and Watford Hospital NHS Trust,

Northwood,

Middlesex HA6 2RN

1 Pickerill HP. On the possibility of establishing skin banks. BFPS 1951;4:157-65.

2 Hickerson WL, Compton C, Fletchall S, Smith LR. Cultured epidermal autografts and allodermis combination for permanent burn wound coverage. Burns 1994;20:S52-6.

3 Navsaria HA, Myers SR, Leigh IM, McKay I. Culturing skin in vitro for wound therapy. Trends in Biorechnology 1995;13:91-100.

4 Cuono CB, Langdon R, Birchall N, Barttelbort S, McGuuire J. Composite autologousallogeneic skin replacement: development and clinical application. Plast Reconstr Surg 1987;80:626-37.

5 Clarke JA. HIV transmission and skin grafts. Lancet 1987;i:983.

6 Van Baare J, Buitenwerf J, Hoekstra J, du Pont JS. Virucidal effect of glycerol as used in donor skin preservation. Burns 1994;20:S77-80.

Council of Europe. Recommendation of the Commitzee of Ministers to Member States on Human Tissue Banking. Strasbourg: Council of Europe, 1994.

8 Steckler D, Eastlund T. Tissue banking: the role of the Regional Blood Centre: an American experience in Minnesota. Med Lab Sci 1991;48:147-54.

Warwick RM, Eastlund T, Fehily D. The role of the blood transfusion service in tissue banking. Vox Sanguinis (in press). 